\title{
Effects of Human Papillomavirus-Associated Cells on Human Immunodeficiency Virus Gene Expression
}

\author{
JULIA R. GAGE, PhD, ANAHAT K. SANDHU, MD, MIKIO NIHIRA, MD,
} MARIA DA GLORIA BONECINI-ALMEIDA, MS, PhD, PAOLO CRISTOFORONI, MD, TADAMITSU KISHIMOTO, MD, DMSc, FREDRICK J. MONTZ, MD, AND

OTONIEL MARTÍNEZ-MAZA, PhD

Objective: To examine the effects of soluble factors secreted by human papillomavirus (HPV)-associated cells on human immunodeficiency virus (HIV) expression.

Methods: Supernatants collected from cultured cervical biopsies and cervical cancer cell lines, and HPVimmortalized and normal keratinocytes were tested for the ability to induce HIV p24 production in two cell lines that contained latent HIV (the U1 monocytic line and the ACH-2 $\mathrm{T}$ cell line). Levels of HIV p24 were measured by enzymelinked immunosorbent assay (ELISA). Culture supernatants were also assayed for the inflammatory cytokines interleukin 6, tumor necrosis factor, and interleukin $1 \beta$ by ELISA.

Results: Supernatants from all epithelial cells tested upregulated HIV p24 expression in the U1 line but not in the ACH-2 cells. Only differentiated normal keratinocytes induced p24 production by ACH-2 cells. Neutralization of the cytokines, particularly interleukin 6, partially reduced the level of HIV-inducing activity in the culture supernatants. Additionally, cervical biopsies from HIV-infected women cultured in vitro also were able to induce HIV in U1 cells but not ACH-2 cells.

Conclusions: Our results suggest that HPV infection of the cervix might influence HIV pathogenesis by inducing the production of immune and inflammatory factors that enhance HIV expression. (Obstet Gynecol 2000;96:879-85. (C) 2000 by The American College of Obstetricians and Gynecologists.)

From the Departments of Obstetrics and Gynecology and Microbiology, Immunology and Molecular Genetics, UCLA School of Medicine, Los Angeles, California; Evandro Chagas Hospital Research Center, Oswaldo Cruz Foundation, Rio de Janeiro, Brazil; Dipartimento di Ginecologia, Universita di Genova, Genoa, Italy; Institute of Molecular and Cellular Biology, Osaka University, Osaka, Japan; and Division of Gynecologic Oncology, Johns Hopkins University, Baltimore, Maryland.

This work was supported by the Universitywide AIDS Research Program grants R96-LA-1101 and R96-LA-1102. J.R.G. is a recipient of the AMGEN Fellowship in the Molecular Biology of HIV/AIDS.
Human papillomaviruses (HPV) cause chronic, perhaps life-long, infections of the uterine cervix and have been associated with cervical cancer. ${ }^{1}$ Human papillomavirus infects basal cells of the cervical epithelium, and completion of its life cycle is linked fastidiously to the state of differentiation of the infected cell. ${ }^{2}$ Human papillomavirus-associated lesions are usually transient and presumably regress as a result of a cellular immune response characterized by infiltration by $\mathrm{T}$ lymphocytes in humans ${ }^{3}$ and animal models. ${ }^{4,5}$ Human papillomavirus then goes through a period of clinical latency but frequently reappears, especially in human immunodeficiency virus (HIV) seropositive women. ${ }^{6}$ Additionally, HIV-infected women have greater frequency ${ }^{7}$ and severity $^{8}$ of HPV-associated cervical dysplasia than uninfected women. Therefore, the presence of HIV, and the immunosuppression associated with HIV infection, exacerbate coexisting HPV infections.

We hypothesize that chronic HPV infections might influence the progression of HIV disease by the following two mechanisms: recruitment of HIV target cells, such as CD4 + T cells and macrophages, into the site of active HPV infection, and inducing production of inflammatory cytokines, including interleukin 6, tumor necrosis factor, and interleukin $1 \beta$. Those inflammatory cytokines induce HIV replication and transcription..$^{9-12}$ Cervicovaginal washings from HIV-infected women have elevated levels of interleukin 6, tumor necrosis factor, and interleukin $1 \beta$, showing that the cytokines are present in vivo. ${ }^{13}$ Interleukin 6 can also induce peripheral blood mononuclear cells to express monocyte chemotactic protein 1, a chemokine involved in recruitment of macrophage precursors to infected tissues. ${ }^{14}$ 
In this study, we examined the ability of HPVassociated epithelial cells and normal human epithelial keratinocytes, and cervical biopsies collected from HIVinfected women, to produce factors that induce HIV expression in monocytes or macrophages and $\mathrm{T}$ cells, using two cell lines that are latently infected with HIV-U1 cells (a monocytic line) and ACH-2 cells (a T cell line). We found that HPV-associated epithelial cells produce inflammatory cytokines, particularly interleukin 6, and that those factors enhance HIV expression in the U1 monocytic cell line.

\section{Materials and Methods}

The cervical cancer cell lines SiHa, HeLa, and HT-3 were obtained from the American Type Culture Collection (Manasses, VA) and maintained under standard culture conditions. HOK-16B cells were provided by Dr. No-Hee Park and maintained as described. ${ }^{15}$ Normal human epidermal keratinocytes, derived from neonatal foreskin (Clonetics Corp., San Diego, CA), were grown according to the supplier's recommendations. Cycling normal human keratinocytes were maintained as subconfluent monolayers, whereas differentiated normal human keratinocytes were grown to confluency, then supplemented with $10 \%$ fetal bovine serum (Sigma Chemical Co., St. Louis, $\mathrm{MO}$ ) and $0.85 \mathrm{mM} \mathrm{CaCl}_{2}$ for 48 hours to induce differentiation.

HeLa, SiHa, HOK-16B, HT-3, and normal human keratinocytes were grown as monolayers to approximately $70 \%$ confluency. The cells were then fed with medium alone or with medium that contained interleukin $6(10 \mathrm{ng} / \mathrm{mL})$, tumor necrosis factor $(10 \mathrm{ng} / \mathrm{mL})$ (R\&D Systems Inc., Minneapolis, MN), or HIV Tat (10 $\mathrm{ng} / \mathrm{mL}$ ) (ImmunoDiagnostics Inc., Bedford, MA) for 24 hours. The cell monolayers were then washed extensively to remove all treatments and refed with fresh untreated medium. The cells subsequently were cultured for 48 hours to allow accumulation of soluble factors in response to cytokine or Tat treatments, and the supernatants were collected for HIV induction assays or cytokine measurements. Where indicated, cytokines present in the culture supernatants were neutralized by the addition of antibodies to interleukin 6 $(1 \mu \mathrm{g} / \mathrm{mL})$ or tumor necrosis factor $(1 \mu \mathrm{g} / \mathrm{mL}$ ) (Biosource International Inc., Camarillo, CA). Interleukin 1 activity was neutralized by pretreating the U1 effector cells with interleukin 1 receptor antagonist $(1 \mu \mathrm{g} / \mathrm{mL})$ (R\&D Systems Inc.) for 1 hour before addition of test supernatants. The levels of neutralizing antibodies and interleukin 1 receptor antagonist were calculated by the manufacturers to block the level of cytokines found in those culture supernatants completely.
Cervical biopsies were collected from HIV-infected women who had abnormal cervical cytology results in a colposcopy clinic, after giving informed consent, as approved by the UCLA Human Subject Protection Committee. Women were enrolled sequentially, regardless of disease status, to determine the potential role of cervical epithelium in induction of HIV gene expression. The specimens were treated with $0.25 \%$ trypsin and $0.1 \%$ ethylenediaminetetra-acetic acid for $30 \mathrm{~min}-$ utes at $37 \mathrm{C}$, and tissues were then gently teased apart and placed in T-25 tissue culture flasks for 72 hours. Culture supernatants were collected and assayed for the ability to induce HIV gene expression in $\mathrm{U} 1$ or $\mathrm{ACH}-2$ cells.

U1/HIV-1 and ACH-2 cells were obtained from Dr. Thomas Folks through the AIDS Research and Reference Reagent Program, Division of AIDS, NIAID, National Institutes of Health. U1 or ACH-2 cells were seeded in 48-well tissue culture plates at a cell density of $10^{5}$ cells in $0.4 \mathrm{~mL}$ per well. An equivalent volume of test or biopsy supernatants or medium containing cytokine controls was added to each well. Cells were incubated for 4 days, and the supernatants were collected for HIV p24 testing, as a measure of HIV induction. HIV p24 levels were determined by enzyme-linked immunosorbent assay (ELISA) (Coulter, Miami, FL), and were done by the UCLA AIDS Institute Core Facility. Statistical significance was determined by analysis of variance.

Kits to measure tumor necrosis factor and interleukin $1 \beta$ in culture supernatants were obtained from Biosource International Inc., and done according to manufacturer's protocols. The ELISA to measure interleukin 6 has been described. ${ }^{16}$

\section{Results}

The epithelial cells chosen for this study included HeLa and SiHa cells, which are derived from cervical cancers and contain HPV-18 and 16, respectively, and HT-3 cells, which are also derived from cervical cancer but contain no known HPV. We also used the HOK-16B cell line, which was derived by transforming oral keratinocytes with the HPV-16 genome by transfection ${ }^{15}$ and which represents an HPV-infected epithelial cell without the inherent genomic alterations caused by longterm culture that are seen in the cervical cancer cell lines. We also examined primary normal human epithelial keratinocytes, which are maintained as actively cycling subconfluent monolayers or induced to differentiate and which represent targets of HPV infection in this model.

We first examined the ability of $\mathrm{U} 1$ and $\mathrm{ACH}-2$ cells 


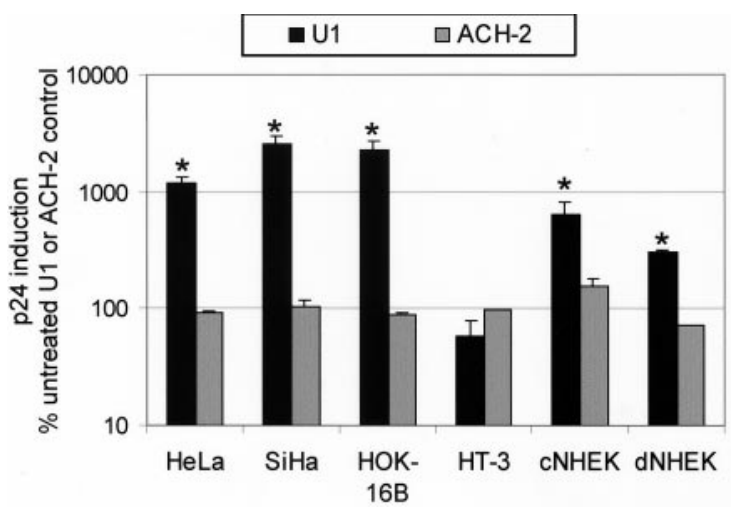

Figure 1. Epithelial cell culture supernatants induced latent HIV in $\mathrm{U} 1$ and ACH-2 cells. U1 cells (black bars) and ACH-2 cells (gray bars) were exposed to culture supernatants collected from epithelial cells. The data shown represent the mean values of the results of two independent experiments and are expressed as the percentage of HIV p24 production by untreated U1 or ACH-2 cells. Error bars represent the standard error of the mean. cNHEK = cycling normal human epidermal keratinocytes; dNHEK $=$ differentiated normal human epidermal keratinocytes. ${ }^{*} P<0.05$.

to respond directly to physiologically relevant doses of interleukin 6, tumor necrosis factor, interleukin $1 \beta$, and Tat, using HIV p24 production as a measure of HIV induction. As expected, HIV p24 antigen production by U1 cells was induced by interleukin 6 and tumor necrosis factor, whereas $\mathrm{ACH}-2$ cells responded only to tumor necrosis factor (not shown). The HIV Tat is a transactivator of viral and cellular gene transcription, which is shed abundantly by HIV-infected cells. The latent HIV in the U1 cell line contains two defective Tat genes ${ }^{17}$ that can be rescued by addition of exogenous recombinant Tat. ${ }^{18}$ The level of Tat used to stimulate epithelial cells in our experiments $(10 \mathrm{ng} / \mathrm{mL})$ was sufficient to induce Tat-mediated effects in other cell types and assays ${ }^{19}$ but was too low to directly enhance HIV expression in $\mathrm{U} 1$ and $\mathrm{ACH}-2$ cells.

Next we examined the ability of epithelial cells to produce factors that induce HIV-1 expression. As shown in Figure 1, supernatants from the HPVassociated cell lines HeLa, SiHa, and HOK-16B readily induced HIV p24 production in the U1 monocytic line. Pretreatment of $\mathrm{SiHa}$ and HOK-16B cells with interleukin 6, tumor necrosis factor, or Tat did not significantly alter the ability of those cells to induce p24 production in U1 cells, whereas pretreatment of HeLa and HT-3 cells with tumor necrosis factor greatly enhanced the level of HIV p24 production in U1 cells (not shown). The cervical cancer cell line HT-3, which does not contain any known HPV, did not induce HIV-1 in the U1 cells without tumor necrosis factor pretreatment, and both cycling and differentiated normal human keratinocytes induced only moderate levels of p24 relative to the HPV-associated cell lines. In contrast, only cycling keratinocytes induced a small but reproducible increase in HIV p24 levels in the ACH-2 T cell line, and that effect was not influenced by any pretreatments (not shown).

The epithelial cell culture supernatants used in the HIV induction assays were examined for inflammatory cytokines interleukin 6, tumor necrosis factor, and interleukin $1 \beta$ (Table 1 ). Only SiHa and HT-3 cells produced levels of interleukin 6 that were detectable by ELISA (more than $5 \mathrm{U} / \mathrm{mL}$ ). SiHa cells produced the highest basal levels of interleukin 6 and were upregulated by all treatments, including Tat, consistent with

Table 1. Inflammatory Cytokine Production by Epithelial Cells

\begin{tabular}{|c|c|c|c|c|c|c|}
\hline & HeLa & $\mathrm{SiHa}$ & HOK-16B & HT-3 & cNHEK & dNHEK \\
\hline \multicolumn{7}{|l|}{ IL-6 $(\mathrm{U} / \mathrm{ml})^{*}$} \\
\hline Medium $^{\dagger}$ & $<5$ & 34 & $<5$ & 16 & $<5$ & $<5$ \\
\hline IL-6 & $<5$ & 67 & $<5$ & 32 & $<5$ & $<5$ \\
\hline TNF & $<5$ & 114 & $<5$ & 53 & $<5$ & $<5$ \\
\hline Tat & $<5$ & 51 & $<5$ & 16 & $<5$ & $<5$ \\
\hline \multicolumn{7}{|c|}{ Tumor necrosis factor $(\mathrm{pg} / \mathrm{mL})$} \\
\hline Medium & $<0.1$ & $<0.1$ & 0.2 & 0.5 & $<0.1$ & 0.1 \\
\hline IL-6 & $<0.1$ & $<0.1$ & 0.2 & 0.3 & $<0.1$ & $<0.1$ \\
\hline TNF & $<0.1$ & 0.1 & $<0.1$ & 0.5 & $<0.1$ & 0.3 \\
\hline Tat & 0.1 & 0.4 & 0.1 & 0.6 & $<0.1$ & 0.2 \\
\hline \multicolumn{7}{|c|}{ IL-1 $\beta(\mathrm{pg} / \mathrm{mL})$} \\
\hline Medium & $<1$ & $<1$ & $<1$ & $<1$ & $<1$ & $<1$ \\
\hline IL-6 & $<1$ & $<1$ & $<1$ & $<1$ & $<1$ & $<1$ \\
\hline TNF & $<1$ & $<1$ & $<1$ & 2.6 & 1 & 1.5 \\
\hline Tat & $<1$ & $<1$ & $<1$ & $<1$ & $<1$ & $<1$ \\
\hline
\end{tabular}

cNHEK = cycling normal human epidermal keratinocytes; $\mathrm{dNHEK}=$ differentiated normal human epidermal keratinocytes; IL-6 = interleukin 6; TNF $=$ tumor necrosis factor.

* Approximately 5 units of interleukin 6 activity per nanogram of protein.

† Cells were pretreated with medium or cytokines, as indicated. 


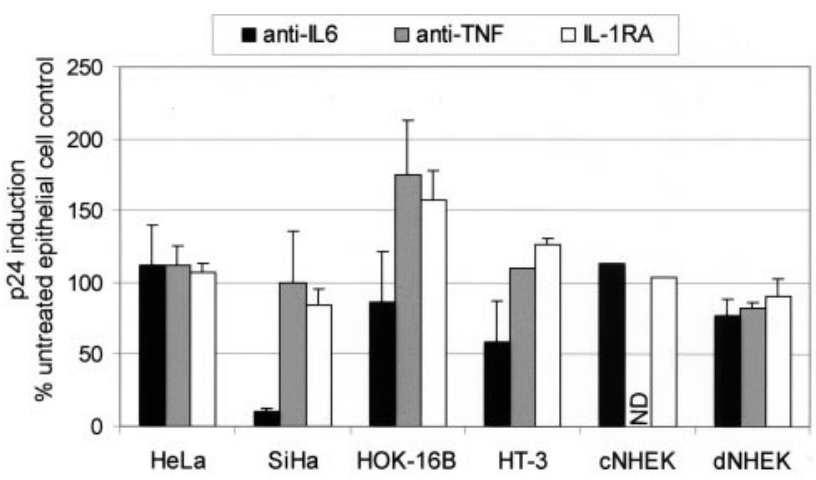

Figure 2. Inflammatory cytokines produced by epithelial cells induced latent HIV in U1 cells. Interleukin 6 (black bars), tumor necrosis factor (gray bars), and interleukin $1 \beta$ (white bars) present in epithelial cell culture supernatants were neutralized and tested for the ability to induce HIV p24 expression. The data represent means of the results of two independent experiments and are expressed as the percentage of p24 production of supernatants without neutralization. Error bars represent the standard error of the mean. IL6 $=$ interleukin 6; TNF $=$ tumor necrosis factor; IL-1RA = interleukin 1 receptor antagonist; $\mathrm{ND}=$ not done. Other abbreviations as in Figure 1.

results from other studies. ${ }^{20}$ In contrast, interleukin 6 production by HT-3 cells increased in response to interleukin 6 and tumor necrosis factor treatments but not to Tat (Table 1). When detectable, the levels of tumor necrosis factor and interleukin $1 \beta$ production by all cell types were extremely low, usually near the limits of detection (over $0.1 \mathrm{pg} / \mathrm{mL}$ and $1 \mathrm{pg} / \mathrm{mL}$, respectively), as shown in Table 1.

To assess the contribution of the individual inflammatory cytokines to HIV induction, epithelial cell culture supernatants were treated with neutralizing antibodies to interleukin 6 or tumor necrosis factor before addition to U1 cells. Interleukin $1 \beta$ activity was inhibited by treating the $\mathrm{U} 1$ cells with excess interleukin 1 receptor antagonist before the addition of test supernatants. As shown in Figure 2, the addition of antiinterleukin 6 antibodies partially reduced induction of p24 by SiHa, HOK-16B, HT-3, and differentiated kera- tinocytes. Neutralization of tumor necrosis factor or interleukin $1 \beta$ did not inhibit $\mathrm{p} 24$ production by most of the epithelial cell supernatants (Figure 2). Supernatants from epithelial cells pretreated with interleukin 6, tumor necrosis factor, and Tat also were neutralized before testing in the U1 assay, and those results are summarized in Table 2. Supernatants collected from SiHa and HT-3 cells, which had the highest levels of interleukin 6 (Table 1), were significantly neutralized by anti-interleukin 6 antibodies. The anti-interleukin 6 antibodies inhibited HIV p24 induction in many supernatants that did not contain detectable interleukin 6 (under $5 \mathrm{U} / \mathrm{mL}$ ) (Table 1). In contrast, neutralization of tumor necrosis factor and interleukin $1 \beta$ activity inhibited HIV induction in only a few instances. Neutralization of those cytokines individually (Figure 2 and Table 2) or simultaneously (not shown) did not completely abrogate p24 production, suggesting that other molecules that were inducing HIV in this system were present in those supernatants. Treatment of U1 and $\mathrm{ACH}-2$ cells with isotype control antibodies had no effect on p24 production (not shown).

Cells from cervical biopsies from HIV-infected women with abnormal cervical cytology results also were tested for the ability to stimulate HIV expression in $\mathrm{U} 1$ and ACH-2 cell lines. All of the supernatants from biopsies cultured in vitro readily induced p24 production in $\mathrm{U} 1$ cells but not in ACH-2 cells (Figure 3). The supernatant from the biopsy of one woman appeared to inhibit HIV p24 production in the $\mathrm{ACH}-2$ cell line.

\section{Discussion}

The vagina and cervix are the first line of physical and immunologic defense against sexually transmitted pathogens, so cervical epithelial cells can be critical in the transmission of HIV. In particular, persistent viral lesions caused by HPV infection can cause chronic

Table 2. Inhibition of HIV Induction in U1 Cells by Neutralization of Inflammatory Cytokines*

\begin{tabular}{|c|c|c|c|c|c|c|c|c|c|c|c|c|c|c|c|c|c|c|}
\hline & \multicolumn{3}{|c|}{ HeLa } & \multicolumn{3}{|c|}{$\mathrm{SiHa}$} & \multicolumn{3}{|c|}{ HOK-16B } & \multicolumn{3}{|c|}{ HT-3 } & \multicolumn{3}{|c|}{ cNHEK } & \multicolumn{3}{|c|}{ dNHEK } \\
\hline & $\begin{array}{l}\text { Anti- } \\
\text { IL-6 }\end{array}$ & $\begin{array}{l}\text { Anti- } \\
\text { TNF }\end{array}$ & $\begin{array}{l}\text { IL-1 } \\
\text { RA }^{\dagger}\end{array}$ & $\begin{array}{l}\text { Anti- } \\
\text { IL-6 }\end{array}$ & $\begin{array}{l}\text { Anti- } \\
\text { TNF }\end{array}$ & $\begin{array}{c}\text { IL-1 } \\
\text { RA }\end{array}$ & $\begin{array}{l}\text { Anti- } \\
\text { IL-6 }\end{array}$ & $\begin{array}{l}\text { Anti- } \\
\text { TNF }\end{array}$ & $\begin{array}{c}\text { IL-1 } \\
\text { RA }\end{array}$ & $\begin{array}{l}\text { Anti- } \\
\text { IL-6 }\end{array}$ & $\begin{array}{l}\text { Anti- } \\
\text { TNF }\end{array}$ & $\begin{array}{c}\text { IL-1 } \\
\text { RA }\end{array}$ & $\begin{array}{l}\text { Anti- } \\
\text { IL-6 }\end{array}$ & $\begin{array}{l}\text { Anti- } \\
\text { TNF }\end{array}$ & $\begin{array}{c}\text { IL-1 } \\
\text { RA }\end{array}$ & $\begin{array}{l}\text { Anti- } \\
\text { IL-6 }\end{array}$ & $\begin{array}{l}\text { Anti- } \\
\text { TNF }\end{array}$ & $\begin{array}{c}\text { IL-1 } \\
\text { RA }\end{array}$ \\
\hline Medium & & & & +++ & & + & + & & & ++ & & & & ND & & + & + & \\
\hline IL-6 & & & & +++ & & & ++ & & & ++ & & & ND & ND & + & ++ & ++ & ++ \\
\hline TNF & ++ & & + & ++ & & & +++ & & & ++ & & & + & + & & & & \\
\hline Tat & & & & +++ & ++ & & +++ & + & & ++ & & & & & & + & & \\
\hline
\end{tabular}

IL-1RA = interleukin 1 receptor antagonist; ND = not done. All other abbreviations as in Table 1.

* Cell culture supernatants were collected from pretreated cells. Cytokines in the supernatants were neutralized and are indicated under each cell type. The level of inhibition is defined by the amount of HIV p24 antigen produced by U1 cells in response to neutralized supernatants relative to the identically produced supernatants without neutralization. $+++=$ greater than $50 \%$ inhibition, $++=25-50 \%$ inhibition, $+=10-25 \%$ inhibition. 


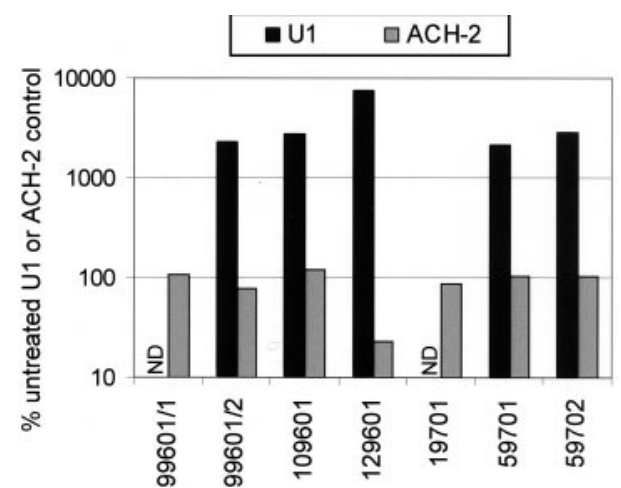

Figure 3. Cervical biopsies cultured in vitro induced HIV in the U1 cell line. Supernatants from cultured cervical biopsies from HIVinfected women were exposed to U1 cells (black bars) or ACH-2 cells (gray bars). Samples $99601 / 1$ and $99601 / 2$ are serial biopsies from the same woman. $\mathrm{ND}=$ not done.

inflammation during induction of anti-HPV immune responses and production of cytokines that can affect HIV expression. Although the tissue culture model presented here did not address issues of transmission directly, it did provide evidence of a potential effect of cervical epithelial cells in HIV activation.

Cell lines that contain HPV (HeLa, SiHa, and HOK16B) and genital epithelial cells without HPV (HT-3 and normal human keratinocytes) were tested for the ability to induce HIV in U1 monocytic cells and ACH-2 T cells. To simulate growth conditions of HPV-infected and HIV-infected individuals in vivo, the epithelial cells were pretreated with the inflammatory cytokines interleukin 6 and tumor necrosis factor, and the HIVencoded transactivating protein Tat. All epithelial cells tested except HT-3 (a HPV-negative line), with or without treatments, were capable of inducing HIV in the U1 monocytic line. Epithelial cells that contained HPV were more potent positive regulators of HIV activation than HPV-negative cells. Only supernatants collected from cycling keratinocytes induced latent HIV-1 in the ACH-2 T cell line, and neutralization of the inflammatory cytokines had no effect on HIV activation. Spear and coworkers ${ }^{21}$ detected a heat-stable activator of T-tropic HIV-1 replication in cervicovaginal lavage samples from HIV-infected and uninfected high-risk women. Although the source of that activator is not known, it is possible that keratinocytes in the genital tract are responsible for it, and perhaps the activator accounts for the HIV-inducing activity in the supernatants from cycling keratinocytes.

Based on neutralization experiments, interleukin 6 was the predominant cytokine involved in inducing HIV in U1 cells, particularly by $\mathrm{SiHa}, \mathrm{HOK}-16 \mathrm{~B}$, and HT-3 cells. Interleukin 6 in the cell supernatants generally correlated with the ability to neutralize antibodies to interleukin 6 to inhibit HIV-1 induction. However, some supernatants that did not contain detectable interleukin 6 also were neutralized by anti-interleukin 6 antibodies, indicating that interleukin 6 is an extremely potent activator of HIV in U1 cells. It is also possible that suboptimal doses of interleukin 6 might synergize with other factors, such as interleukin 10, to induce HIV in this system. ${ }^{11,12,22}$ HT-3 cells, which make adequate levels of interleukin 6, were poor inducers of HIV activation. It is possible that HPV in the other cervical cancer cell lines was responsible for the greater potencies of those cell types. That could be due to HPV gene products, such as the transactivators E6 or E7, or to cellular genes, other than the inflammatory cytokines examined in this study, that have been turned on by HPV transactivators.

Tumor necrosis factor was not detectable in most supernatants, and when present, was not always inhibited by anti-tumor necrosis factor neutralizing antibodies. In some cases, anti-tumor necrosis factor antibodies inhibited HIV induction although no detectable tumor necrosis factor was present. Our results indicate that tumor necrosis factor activity in this system might be potentiated by other factors, as with interleukin 6 . Tumor necrosis factor also synergizes with interleukin 10 to activate HIV in monocytes. ${ }^{22}$ Interleukin $1 \beta$ was not detected in most supernatants, and the addition of interleukin 1 receptor antagonist to the epithelial cell supernatants rarely inhibited HIV activation. Therefore, interleukin $1 \beta$ and its receptor antagonist probably have little effect in activating HIV in this system.

In support of our hypothesis that cervical epithelial cells can enhance HIV pathogenesis, cervical biopsies from HIV-infected women uniformly showed an ability to induce p24 expression in the U1 monocytic line. Because biopsies contain a heterogenous mixture of cell types, including lymphoid cells and epithelial cells, the origin of the HIV-inducing activity cannot be determined from this system. However, this cell population clearly has the ability to influence HIV expression. Because of the limited number of biopsy cultures, neutralization experiments were not possible with biopsy supernatants, so participation of cytokines in the induction of HIV by cervical explants could not be determined from this study. However, Woodworth and Simpson ${ }^{23}$ showed expression of inflammatory cytokines by cultured normal exocervical and endocervical cells, providing further evidence that the cervical environment is rich in HIV-inducing molecules. A recent cross-sectional study by Luque et $\mathrm{al}^{24}$ also found an association between active HPV disease and high levels of HIV RNA in plasma.

Although HIV tropism is primarily determined by expression of CD4 and coreceptors on the cell sur- 
face, ${ }^{25,26}$ Henderson and Calame ${ }^{27}$ determined that a particular transcription factor, CCAAT/enhancer binding protein $\beta$, is important for replication in macrophages but not $T$ cells. Interleukin 6 signal transduction can proceed by two pathways, ${ }^{28}$ activation of signal transducer and activator of transcription 3, or CCAAT/enhancer binding protein $\beta$. Activated CCAAT/enhancer binding protein $\beta$ binds to the interleukin 6-responsive element in the interleukin 6 promoter and to several acute-phase proteins and cytokine gene promoters, such as those for tumor necrosis factor and interleukin $8 .{ }^{28}$ There are two CCAAT/enhancer binding protein $\beta$ binding sites in HIV, which apparently are used only in macrophages. ${ }^{27}$ Therefore, it is possible that interleukin 6 produced by HPV-infected epithelial cells induces HIV p24 production in monocytes by enhancing that interleukin 6 signaling pathway.

Human papillomavirus infection might contribute to HIV pathogenesis by inducing chronic expression of inflammatory cytokines, which are capable of upregulating HIV replication in macrophages, and by producing HPV-induced molecule(s) that might activate HIV replication and transcription. Our results indicate that HPV-associated epithelial cells can enhance HIV replication in monocytes and suggest that the effect is mediated by the secretion of cytokines, especially interleukin 6 , by epithelial cells.

\section{References}

1. Reeves WC, Rawls WE, Brinton LA. Epidemiology of genital papillomaviruses and cervical cancer. Rev Infect Dis 1989;11:42639.

2. Howley PM. Papillomaviridae: The viruses and their replication. In: Fields BN, Knipe DN, eds. Fields virology. 3rd ed. New York: Raven Press, 1996:2045-76.

3. Coleman N, Birley HD, Renton AM, Hanna NF, Ryait BK, Byrne $\mathrm{M}$, et al. Immunological events in regressing genital warts. Am J Clin Pathol 1994;102:768-74.

4. Knowles G, O'Neil BW, Campo MS. Phenotypical characterization of lymphocytes infiltrating regressing papillomas. J Virol 1996;70: 8451-8.

5. Selvakumar R, Schmitt A, Iftner T, Ahmed R, Wettstein FO, Regression of papillomas induced by cottontail rabbit papillomavirus is associated with infiltration of CD8 + cells and persistence of viral DNA after regression. J Virol 1997;71:5540-8.

6. Fruchter RG, Maiman M, Sedlis A, Bartley L, Camilien L, Arrastia $\mathrm{CD}$. Multiple recurrences of cervical intraepithelial neoplasia in women with the human immunodeficiency virus. Obstet Gynecol 1996;87:338-44.

7. Eckert LO, Watts DH, Koutsky LA, Hawes SE, Stevens CE, Kuypers J, et al. A matched prospective study of human immunodeficiency virus serostatus, human papillomavirus DNA, and cervical lesions detected by cytology and colposcopy. Infect Dis Obstet Gynecol 1999;7:158-64.

8. Fruchter RG, Maiman M, Sillman FH, Camilien L, Webber CA, Kim DS. Characteristics of cervical intraepithelial neoplasia in women infected with the human immunodeficiency virus. Am J Obstet Gynecol 1994;171:531-7.

9. Granowitz EV, Saget BM, Wang MZ, Dinarello CA, Skolnik PR. Interleukin 1 induces HIV-1 expression in chronically infected U1 cells: Blockade by interleukin 1 receptor antagonist and tumor necrosis factor binding protein type 1. Mol Med 1995;1: $667-77$.

10. Kitamura K, Zaki SR, Greer PW, Sinha SD, Folks TM. Tumor necrosis factor-alpha induces circular forms of human immunodeficiency virus type-1 DNA in the persistently infected low-level expressing cell line, ACH-2. Virus Res 1993;27:113-8.

11. Poli G, Bressler P, Kinter A, Duh E, Timmer WC, Rabson A, et al. Interleukin 6 induces human immunodeficiency virus expression in infected monocytic cells alone and in synergy with tumor necrosis factor $\alpha$ by transcriptional and post-transcriptional mechanisms. J Exp Med 1990;172:151-8.

12. Poli G, Kinter AL, Fauci AS. Interleukin 1 induces expression of the human immunodeficiency virus alone and in synergy with interleukin 6 in chronically infected U1 cells: Inhibition of inductive effects by the interleukin 1 receptor antagonist. Proc Natl Acad Sci U S A 1994;91:108-12.

13. Bélec L, Gherardi R, Payan C, Prazuck T, Malkin JE, Tévi-Bénissan $\mathrm{C}$, et al. Proinflammatory cytokine expression in cervicovaginal secretions of normal and HIV-infected women. Cytokine 1995;7: $568-74$.

14. Biswas P, Delfanti F, Bernasconi S, Mengozzi M, Cota M, Polentarutti $\mathrm{N}$, et al. Interleukin-6 induces monocyte chemotactic protein-1 in peripheral blood mononuclear cells and in the U937 cell line. Blood 1998;91:258-65.

15. Park NH, Min BM, Li S, Huang MZ, Cherick HM, Doniger J. Immortalization of normal human oral keratinocytes with type 16 human papillomavirus. Carcinogenesis 1991;12:1627-31.

16. Miles SA, Rezai AR, Salazar-González JF, vander Meyden M, Stevens RH, Logan DM, et al. AIDS Kaposi sarcoma-derived cells produce and respond to interleukin 6. Proc Natl Acad Sci U S A 1990;87:4068-72.

17. Emiliani S, Fischle W, Ott M, Van Lint C, Amella CA, Verdin E. Mutations in the tat gene are responsible for human immunodeficiency virus type 1 postintegration latency in the U1 cell line. J Virol 1998;72:1666-70.

18. Cannon P, Kim SH, Ulich C, Kim S. Analysis of Tat function in human immunodeficiency virus type 1-infected low-levelexpression cell lines U1 and ACH-2. J Virol 1994;68:1993-7.

19. Ensoli B, Gendelman R, Markham P, Fiorelli V, Colombini S, Raffeld M, et al. Synergy between basic fibroblast growth factor and HIV-1 Tat protein in induction of Kaposi's sarcoma. Nature 1994;371:674-80.

20. Ambrosino C, Ruocco MR, Chen X, Mallardo M, Baudi F, Trematerra S, et al. HIV-1 Tat induces the expression of the interleukin-6 (IL6) gene by binding to the IL6 leader RNA and by interacting with CAAT enhancer-binding protein beta (NF-IL6) transcription factors. J Biol Chem 1997;272:14883-92.

21. Spear GT, al-Harthi L, Sha B, Saarloos MN, Hayden M, Massad LS, et al. A potent activator of HIV-1 replication is present in the genital tract of a subset of HIV-1-infected and uninfected women. AIDS 1997;11:1319-26.

22. Weissman D, Poli G, Fauci AS. IL 10 synergizes with multiple cytokines in enhancing HIV production in cells of monocytic lineage. J Acquir Immune Defic Syndr Hum Retrovirol 1995;9: 442-9.

23. Woodworth CD, Simpson S. Comparative lymphokine secretion by cultured normal human cervical keratinocytes, papillomavirusimmortalized, and carcinoma cell lines. Am J Pathol 1993;142: 1544-55. 
24. Luque AE, Demeter LM, Reichman RC. Association of human papillomavirus infection and disease with magnitude of human immunodeficiency virus type 1 (HIV-1) RNA plasma level among women with HIV-1 infection. J Infect Dis 1999;179:1405-9.

25. Alkhatib G, Combadiere C, Broder CC, Feng Y, Kennedy PE, Murphy PM, et al. CC CKR5: A RANTES, MIP-1 alpha, MIP-1 beta receptor as a fusion cofactor for macrophage-tropic HIV-1. Science 1996;272:1955-8.

26. Choe H, Farzan M, Sun Y, Sullivan N, Rollins B, Ponath PD, et al. The beta-chemokine receptors CCR3 and CCR5 facilitate infection by primary HIV-1 isolates. Cell 1996;85:1135-48.

27. Henderson AJ, Calame KL. CCAAT/enhancer binding protein $(\mathrm{C} / \mathrm{EBP})$ sites are required for $\mathrm{HIV}-1$ replication in primary macrophages but not CD4+ T cells. Proc Natl Acad Sci U S A 1997;94:8714-9.

28. Kishimoto T, Akira S, Narazaki M, Taga T. Interleukin-6 family of cytokines and gp130. Blood 1995;86:1243-54.
Address reprint requests to: Otoniel Martínez-Maza, PhD Department of Microbiology, Immunology, E Molecular Genetics

University of California Los Angeles, School of Medicine Los Angeles, CA 90095-1747

E-mail:omartinez@mednet.ucla.edu

Received March 10, 2000.

Received in revised form June 23, 2000.

Accepted August 17, 2000.

Copyright (C) 2000 by The American College of Obstetricians and Gynecologists. Published by Elsevier Science Inc. 